\title{
Pengembangan Multimedia Interaktif Model Games untuk Meningkatkan Respon Mahasiswa pada Mata Kuliah Organisasi dan Arsitektur Komputer
}

\author{
Kadek Agus Hendra Pujawan*
}

Politeknik Ganesha Guru, Denpasar, Bali

\begin{tabular}{l} 
A R T I C L E I N F O \\
\hline Article history: \\
Received 20 November \\
2017 \\
Received in revised form \\
12 Desember 2017 \\
Accepted 15 Januari 2018 \\
Available online 25 \\
Februari 2018 \\
Kata Kunci: \\
Multimedia Interaktif, \\
Games, Dick and Carey \\
Keywords: \\
Interactive Multimedia, \\
Games, Dick and Carey
\end{tabular}

\begin{abstract}
A B S T R A K
Tujuan penelitian ini adalah (1) Untuk membuat multimedia interaktif model games yang layak digunakan untuk mahasiswa Politeknik Ganesha Guru pada mata kuliah organisasi dan arsitektur komputer (2) Untuk mengetahui tingkat kelayakan multimedia interaktif model games menurut ahli isi, ahli media dan ahli desain pembelajaran (3) Untuk mengetahui respon mahasiswa terhadap pengembangan multimedia interaktif model games pada mata kuliah organisasi dan arsitektur komputer. Penelitian ini menggunakan model pengembangan Dick and Carey yang melibatkan mahasiswa semester I Politeknik Ganesha Guru pada Program studi Manajemen Informatika. Berdasarkan hasil analisis data yang diperoleh dari aspek kelayakan isi yang dilakukan oleh ahli isi menunjukan bahwa produk sudah sesuai dengan SAP mata kuliah Organisasi dan arsitektur komputer. Pengujian yang dilakukan oleh ahli media memperoleh hasil kalkulasi sebesar $87 \%$ berada pada kualifikasi baik. Pengujian yang dilakukan oleh ahli desain pembelajaran memperoleh hasil kalkulasi sebesar $88 \%$ berada pada kualifikasi baik. User/dosen pengajar memberikan respon baik. Uji coba lapangan yang dilakukan memperoleh hasil kalkulasi sebesar $90 \%$ berada pada kualifikasi sangat baik.
\end{abstract}

\section{A B S T R A C T}

The aims of this study were (1) to create an interactive multimedia by using games which is proper used by Politeknik Ganesha Guru students in computer organization and architecture course. (2) to know the feasibility level of interactive multimedia by using games according to content expert, media expert and learning design expert in computer organization and architecture course. (3) to know the students' response to the development of interactive multimedia by using games in computer organization and architecture course. This study used Dick and Carey as the development model which invoved first semester students of Politeknik Ganesha Guru in Informatics Management Study Program. Based on the result of the data analysis from the content feasibility aspect made by the content expert indicated that the product is in accordance with the SAP of Computer Organization and Architecture courses. Tests conducted by media experts obtained a calculation result of $87 \%$ which is being in good qualification. Tests conducted by the design of learning experts obtained a calculation result of $88 \%$ which are in good qualification. The user/lecturer gave a good response. Field trials conducted got a result of $90 \%$ calculation which are in excellent qualification.

\footnotetext{
* Corresponding author.

E-mail addresses: hendrapoltekG2Stikom@gmail.com (Kadek Agus Hendra Pujawan)
} 


\section{Pendahuluan}

Di era digital saat ini Teknologi informasi menjadi salah satu faktor yang sangat mempeengaruhi proses belajar mengajar dalam dunia pendidikan, baik sebagai sumber belajar, penyampaian pesan, maupun sarana sebagai pendukung proses pembelajaran, tenaga pengajar bisa berperan sebagai fasilitator dalam proses pembelajaran. Secara keseluruhan kondisi ini dapat membantu mencapai tujuan akademis yang ditetapkan untuk pendidik institusi pendidikan tinggi. (Matukhin \& Zhitkova, 2015).

Salah satu produk pembelajaran yaitu multimedia, pembelajaran multimedia melibatkan beberapa unsur media yaitu teks, gambar, ilustrasi, animasi, narasi, hingga presentasi slide tatap muka yang berisi grafis dan kata-kata yang diucapkan (Mayer, 2014). Multimedia yang efektif ialah multimedia yang secara interaktif mampu mengajak peserta didik untuk ikut membangun atau menumbuhkan pengetahuan peserta didik secara mandiri.(Prismanata, 2017).

Politeknik Ganesha Guru adalah perguruan tinggi berbasis Teknologi Informasi yang dalam proses belajar mengajar memanfaatkan teknologi komputer, namun tidak terlaksana sepenuhnya karena media yang ditampilkan hanya sebatas teks dan gambar hingga menyebabkan mahasiswa menjadi jenuh yang berdampak pada kurangnya respon mahasiswa terhadap mata kuliah organisasi dan arsitektur komputer. Untuk mengatasi masalah tersebut sangat diperlukan multimedia yang dapat merangsang rasa ingin tahu dan mampu meningkatkan respon belajar peserta didik.

Dari hasil wawancara dan hasil observasi terhadap mahasiswa semester 3 Program studi D3 Manajemen informatika yang dominan menyatakan bahwa karakteristik dan kegemaran mereka cenderung menuju ke arah permainan/games, dari temuan tersebut peneliti mencoba mengembangkan sebuah multimedia interaktif model permainan/games yang nantinya diharapkan mampu meningkatkan respon mahasiswa terhadap mata kuliah organisasi dan arsitektur komputer.

Model permainan merupakan salah satu bentuk model yang didesain untuk membangkitkan kegembiraan pada mahasiswa sehingga dapat meningkatkan kemungkinan tersimpannya lebih lama konsep, pengetahuan ataupun keterampilan yang diharapkan dapat mereka peroleh dari permainan tersebut. Keseluruhan model permainan ini memiliki komponen dasar sebagai pembangkit motivasi dengan memunculkan cara berkompetisi untuk mencapai sesuatu. Interaksi berbentuk permainan akan bersifat instruksional apabila pengetahuan dan keterampilan yang terdapat di dalamnya bersifat akademik dan mengandung unsur pelatihan. Sebuah bentuk permainan disebut intruksional apabila didalamnya terdapat tujuan pembelajaran yang harus dicapai (Munir, 2010). Bentuk permainan yang disajikan di sini tetap mengacu pada proses pembelajaran, dan materi yang disajikan sesuai dengan SAP mata kuliah organisasi dan arsitektur komputer dengan program multimedia berformat ini diharapkan terjadi aktifitas belajar sambil bermain sehingga tujuan pembelajaran tercapai. Tujuan permainan dalam Multimedia interaktif ini digunakan untuk memperoleh beragam informasi, seperti fakta, Prinsip, struktur, proses, dan sistem yang dinamis, kemampuan dalam hal memecahkan masalah, pengambilan keputusan, kemampuan kerja sama, kemampuan sosial seperti berkomunikasi, sikap, etika; dan berbagai kemampuan insidental (Rusman, 2012).

\section{Metode}

Pengembangan multimedia interaktif model games ini termasuk dalam jenis penelitian Research and Development. Penelitian ini akan menghasilkan produk berupa multimedia interaktif model games pada pembelajaran organisasi dan arsitektur komputer. Penelitian ini dilaksanakan di Perguruan tinggi Politeknik Ganesha Guru yang beralamat di Jl. Teuku Umar Bar. (Marlboro) No.27, Pemecutan Klod, Denpasar Bar., Kota Denpasar, Bali. Subjek dalam penelitian ini adalah mahasiswa semester 3 Program studi D3 Manajemen Informatika, Politeknik Ganesha Guru. Validator yang terdiri dari ahli desain pembelajaran, ahli media dan ahli isi

Metode Penelitian yang digunakan adalah model penelitian pengembangan Dick \& Carey. Prosedur ini dipilih karena langkah pada model Dick and Carey menunjukan hubungan yang sangat jelas, dan tidak terputus antara langkah yang satu dengan yang lainya (Dadang Supriatna, 2009). Langkahlangkah pengembangan yang dilakukan terdiri atas lima langkah yaitu (1) Menentukan mata kuliah yang menjadi obyek pengembangan; (2) Menganalisis segala sesuatu yang dibutuhkan dalam pengembangan draft seperti analisis tujuan dan karakteristik mata pelajaran, analisis sumber belajar dan analisis karakteristik pebelajar; (3) Proses pengembangan media; (4) Produksi; (5) Tinjauan ahli dan uji coba terhadap produk, Uji coba meliputi tanggapan ahli isi, ahli media, ahli desain, uji coba user/dosen, dan uji coba lapangan terkait kelayakan multimedia interaktif terhadap respon mahasiswa.

Data yang disajikan menggunakan analisis statistik deskriptif. Statistik deskriptif adalah statistik yang digunakan untuk menganalisis data dengan cara mendeskripsikan atau menggambarkan 
data yang telah terkumpul sebagaimana adanya tanpa bermaksud membuat kesimpulan yang berlaku untuk umum atau generalisasi (Sugiyono, 2012). Selanjutnya untuk menghitung prosentase keseluruhan subyek digunakan rumus sebagai berikut.

$$
P=\frac{\sum(\text { jawaban } \times \text { bobot terting } g i)}{n \times \text { bobot tertinggi }} \times 100 \% \quad \text { (Arikunto, 2008:35) }
$$

Keterangan:

$$
\begin{array}{ll}
\mathrm{P} & : \text { Prosentase } \\
\Sigma & : \text { Jumlah } \\
\mathrm{n} & : \text { Jumlah seluruh item angket }
\end{array}
$$

Untuk dapat memberikan makna dalam pengambilan keputusan digunakan ketetapan menggunakan tabel konversi tingkat pencapaian dengan Skala 5 seperti tersaji pada tabel 1. Berikut adalah tabel konversi tingkat pencapaian dengan skala 5.

Tabel 1. Konversi Tingkat Pencapaian dengan Skala 5

\begin{tabular}{cll}
\hline Tingkat Pencapaian (\%) & \multicolumn{1}{c}{ Kualifikasi } & \multicolumn{1}{c}{ Keterangan } \\
\hline $90-100$ & Sangat Baik & Tidak perlu direvisi \\
$75-89$ & Baik & Tidak perlu direvisi \\
$65-74$ & Cukup & Direvisi \\
$55-64$ & Kurang & Direvisi \\
$0-54$ & Sangat Kurang & Direvisi \\
\hline
\end{tabular}

(Arikunto, 2008:35)

\section{Hasil dan pembahasan}

Berikut adalah hasil pengembangan multimedia interaktif model games pada mata kuliah Organisasi dan arsitektur komputer.

1. Menentukan mata kuliah yang menjadi obyek pengembangan, Mata kuliah yang dikembangkan dalam multimedia interaktif yaitu mata kuliah Organisasi dan arsitektur komputer dengan pokok bahasan kinerja komputer, perangkat input, proses dan output hingga bagian bagian processor semua pokok bahasan mengacu pada SAP Organisasi dan arsitektur komputer.

2. Menganalisis segala sesuatu yang dibutuhkan dalam pengembangan draft seperti analisis tujuan dan karakteristik mata pelajaran, analisis sumber belajar dan analisis karakteristik pebelajar; dalam hal ini peneliti melakukan observasi terkait pengembangan multimedia interaktif seperti mencari kegemaran mahasiswa khususnya program studi Manajemen Informatika, hasil observasi dan wawancara yang dilakukan diperoleh data kegemaran mahasiswa yaitu gemar memainkan games, dari hasil tersebut dikembangkanlah multimedia interaktif model games pada mata kuliah organisasi dan arsitektur komputer.

3. Proses pengembangan media terdiri dari pembuatan rancangan storyboard dan hasil rancang bangun produk. software yang digunakan untuk membuat multimedia interaktif model games yaitu Flash CS 5 , untuk input suara menggunakan aplikasi Cool edit pro, dan perekam materi menggunakan Camtasia studio.

Berikut adalah tampilan produk multimedia interaktif model games pada mata kuliah Organisasi dan arsitektur komputer. 


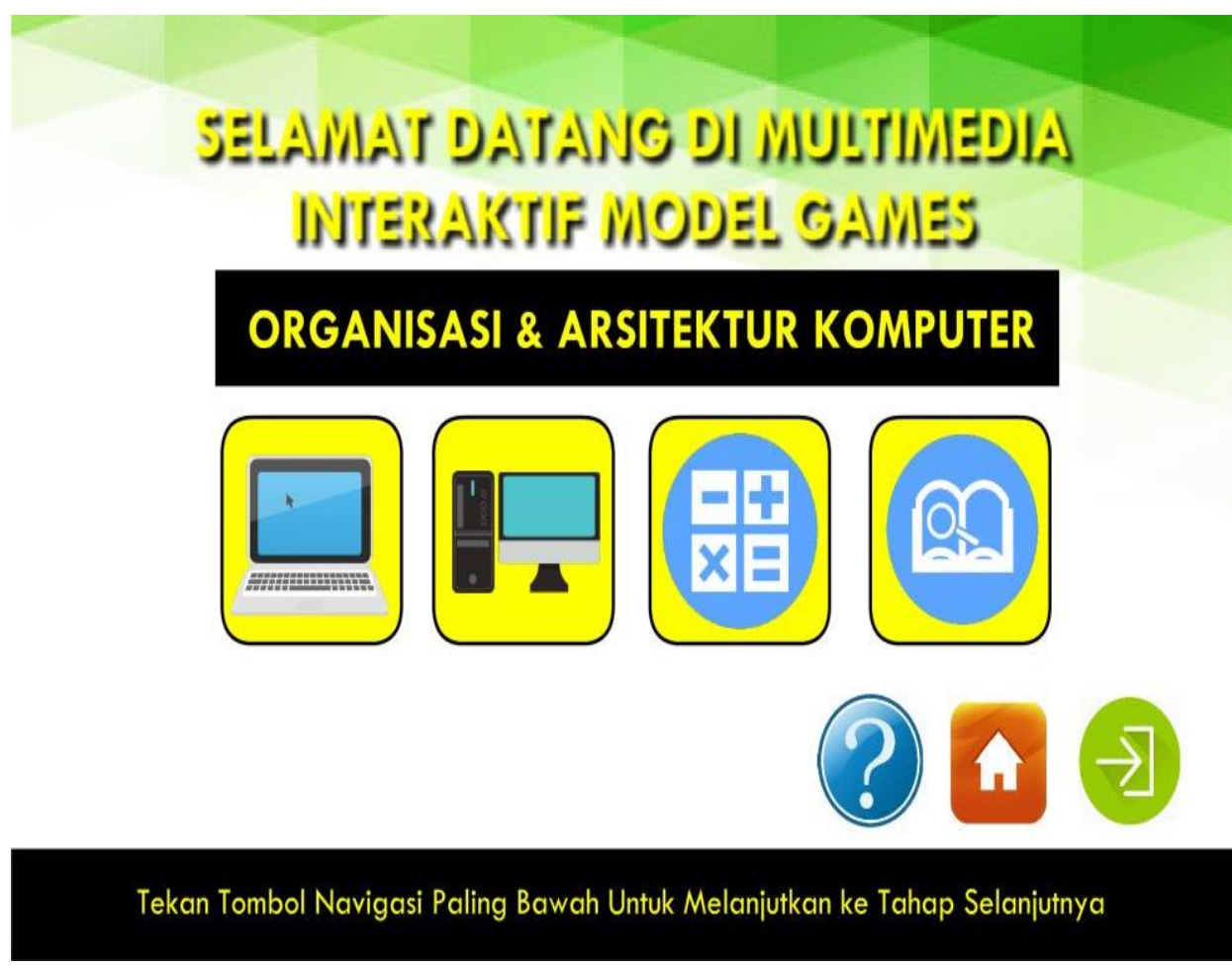

Gambar 1. Tampilan Intro

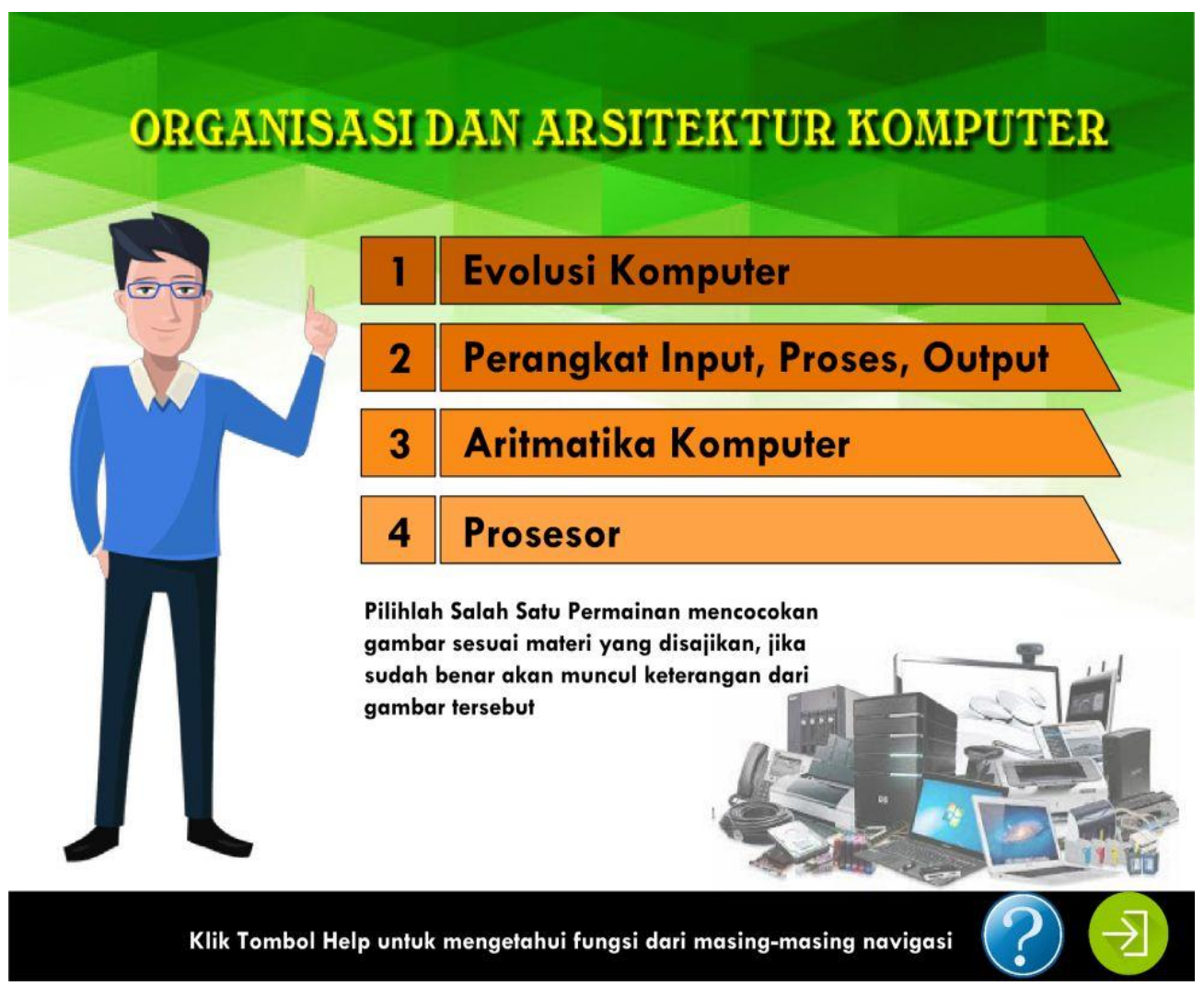

Gambar 2. Tampilan Menu utama 


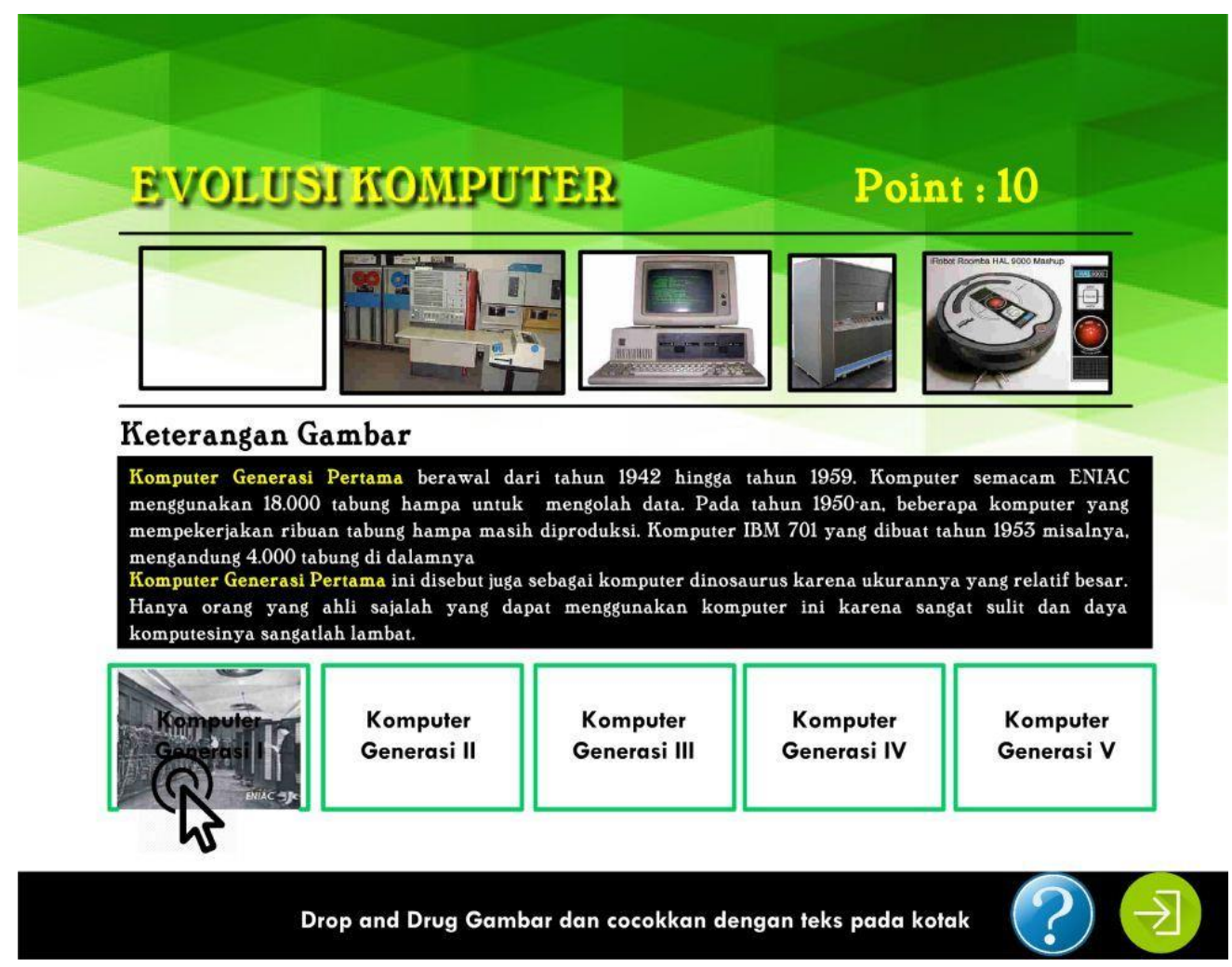

Gambar 3. Tampilan Games Evolusi Komputer

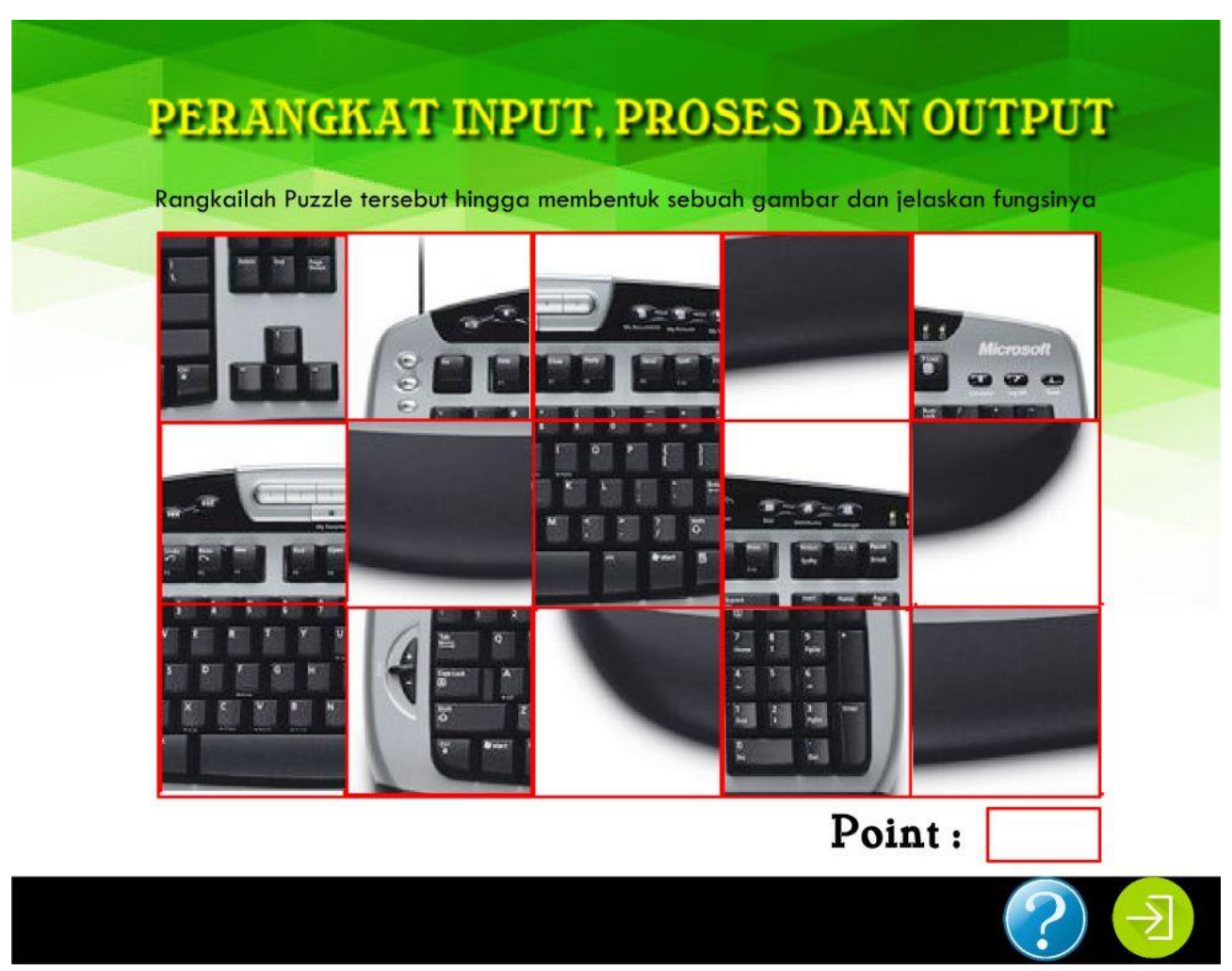

Gambar 4. Tampilan Games Perangkat Input, Proses, Output 


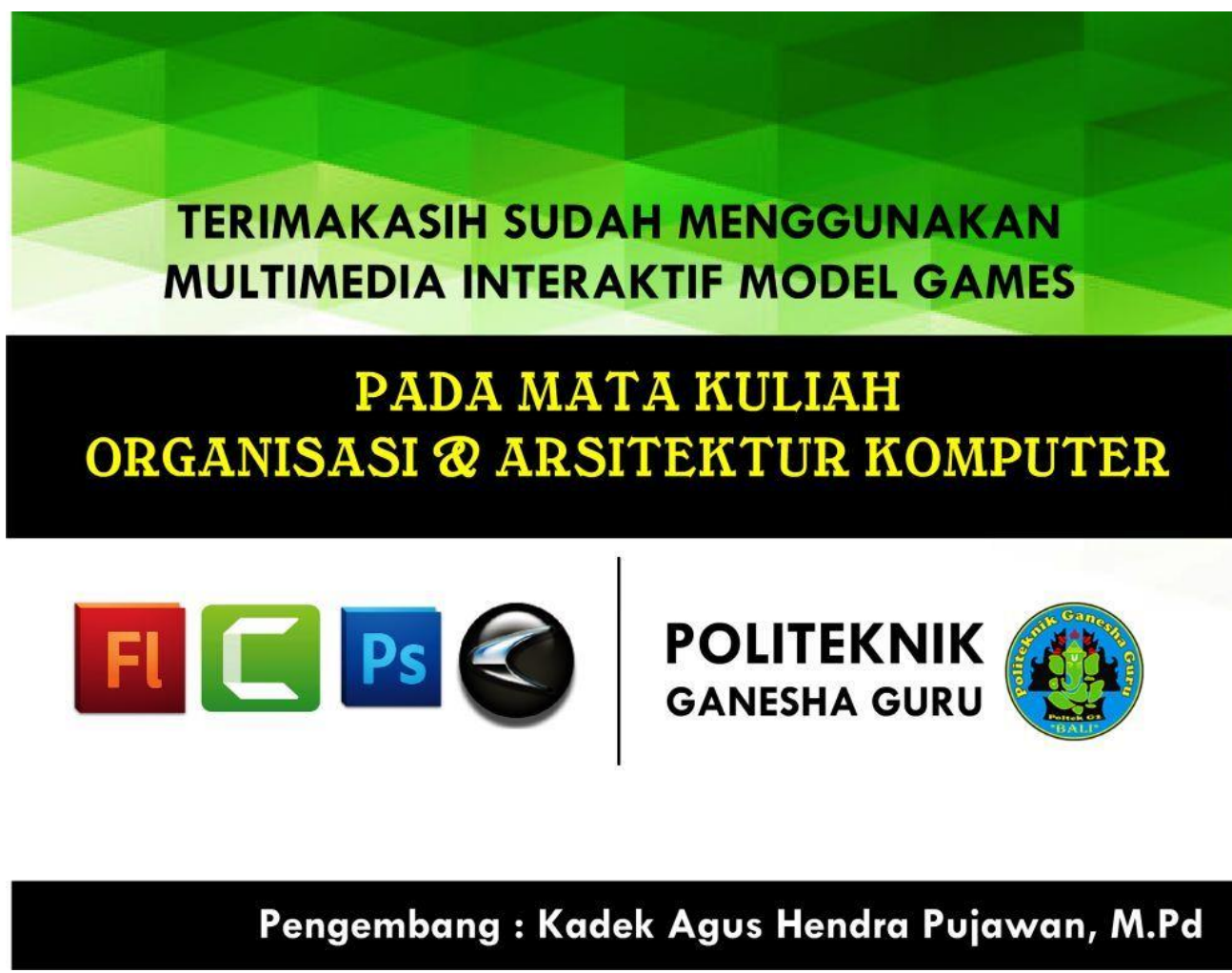

Gambar 5. Tampilan Ending

4. Produksi, dalam tahap ini peneliti langsung ke proses compile/run hasil pengembangan produk dan publishing ke dalam sebuah file ber extensi .exe sebagai master program.

5. Uji coba meliputi tanggapan ahli isi, ahli media, ahli desain pembelajaran, uji coba user/dosen, uji coba untuk mencari respon mahasiswa. Berikut adalah hasil ujicoba dari pengembangan multimedia interaktif berbasis games pada mata kuliah organisasi dan arsitektur komputer.

(1) Penilaian Ahli media

Berdasarkan hasil penilaian ahli media, maka dapat dihitung prosentase tingkat pencapaian multimedia interaktif model games sebagai berikut.

$$
P=\frac{\sum(\text { jawaban } \times \text { bobot tertingg } i)}{n \times \text { bobot terting } i} \times 100 \%
$$

Ditetapkan bobot setiap butir dalam kreteria angket adalah 5, maka prosentasi dihitung. Pertama mencari jumlah skor per item kreteria dan jumlah hasil kali bobot tertinggi dengan jumlah item. Dari tahap itu selanjutnya prosentase dihitung: $157: 180 \times 100 \%=87 \%$. Hasil kalkulasi sebesar $87 \%$ berada pada kualifikasi baik, sehingga multimedia interaktif model games tidak perlu di revisi.

(2) Penilaian Ahli desain

Berdasarkan hasil penilaian ahli desain maka dapat dihitung prosentase tingkat pencapaian multimedia interaktif model games sebagai berikut.

$$
P=\frac{\sum(\text { jawaban } \times \text { bobot tertinggi })}{n \times \text { bobot tertinggi }} \times 100 \%
$$

Ditetapkan bobot setiap butir dalam kreteria angket adalah 5, maka prosentasi dihitung. Pertama mencari jumlah skor per item kreteria dan jumlah hasil kali bobot tertinggi dengan jumlah item. Berdasarkan tahap itu, selanjutnya prosentase dihitung: $88: 100 \times 100 \%=88 \%$. Hasil kalkulasi sebesar $88 \%$ berada pada kualifikasi baik, sehingga multimedia interaktif model games tidak perlu direvisi. 
(3) Penilaian Ahli isi

Berdasarkan hasil penilaian ahli isi maka dapat dilihat isi materi pembelajaran dalam multimedia interaktif sudah sesuai dengan SAP mata kuliah Organisasi dan arsitektur komputer dan tidak perlu di revisi

(4) Penilaian User/Dosen

Materi dalam multimedia interaktif sudah sesuai dengan kriteria sebuah multimedia interaktif pada mata kuliah Organisasi dan arsitektur komputer yang akan digunakan di semester III Program studi D3 Manajemen Informatika

(5) Respon Mahasiswa

Prosentase $=90: 100 \times 100 \%=90 \%$. Hasil kalkulasi sebesar 90\% jika di konversi dengan tabel konversi tingkat pencapaian dengan skala 5 hasil kalkulasi berada pada kualifikasi sangat baik, sehingga multimedia interaktif model games tidak perlu direvisi.

Multimedia interaktif model games pada mata kuliah organisasi dan arsitektur komputer dapat terlihat dengan mengenali pola pembelajaran melalui permainan yang dirancang sedemikian rupa. Dalam model games yang dirancang pada multimedia interaktif menggunakan konsep mencocokan gambar, jadi ketika gambar tersebut cocok maka mendapat tambahan point, selain tambahan point dalam multimedia interaktif juga akan menampilkan penjelasan terkait materi yang disajikan. Konsep yang kedua yaitu game puzzle, konsep tersebut diawali dengan gambar acak, selanjutnya kita merangkai gambar tersebut hingga benar, lalu kita menyebutkan nama dari perangkat tersebut dan menjelaskan fungsinya. Dengan konsep tersebut membuat pembelajaran organisasi dan arsitektur komputer lebih menantang dan lebih menyenangkan. Keseluruhan permainan memiliki komponen dasar sebagai pembangkit motivasi belajar mahasiswa dengan memunculkan cara berkompetensi untuk mencapai sesuatu yang diharapkan, yaitu tujuan pembelajaran organisasi dan arsitektur komputer.

Menurut Rusman (2012) menyebutkan bahwa Tahapan yang harus ditembuh dalam pembuatan instructional games sebagai model pembelajaran, yaitu (1) tujuan, setiap permainan harus memiliki tujuan, yaitu tujuan pembelajaran yang telah ditetapkan. Pada beberapa instructional games tujuan diidentikan dengan pencapaian skor yang diharapkan. (2) aturan, yaitu penetapan setiap tindakan yang dapat dilakukan dan yang tidak dapat dilakukan oleh pemain. Aturan tersebut dapat berubah selama hal tersebut untuk menghindari kelemahan- kelaemahan yang terjadi dengan aturanaturan tersebut atau bahkan untuk membuat permainan itu lebih menarik. (3) khayalan, permainan sering bergantung pada pengembangan imajinasi untuk memberikan motivasi kepada pemain. (4) Hiburan, hampir semua permainan untuk menghibur, permainan dalam pembelajaran itu berperan meningkatkan respon belajar peserta didik.

Dalam proses pengembangan multimedia interaktif model games pada matakuliah organisasi dan arsitektur komputer dibuat sesuai dengan rancangan storyboard, selanjutnya mulai mengembangkan dengan menggunakan aplikasi Adobe Flash Cs 5, Aplikasi tersebut cocok digunakan karena fitur-fitur nya sangat mendukung dalam pembuatan sebuah aplikasi berbasis multimedia. Produk tersebut di distribusikan dengan mempublish ke dalam format .exe.

Hasil analisis ujicoba dilaksanakan dengan melibatkan ahli isi, ahli media dan ahli desain pembelajaran, ujicoba tersebut menyatakan bahwa Multimedia interaktif model games pada mata kuliah organisasi dan arsitektur komputer layak digunakan di Politeknik Ganesha Guru, namun dalam perjalananya ahli media dan ahli desain pembelajaran menemukan beberapa revisi antara lain dalam pemilihan gambar yang digunakan dalam puzzle hendaknya lebih menarik rasa penasaran mahasiswa sehingga mahasiswa lebih tertantang untuk belajar menggunakan multimedia interaktif model games. Selain itu ahli media juga menyebutkan bahwa bahasa dalam multimedia interaktif harus konsisten, jadi yang sebelumnya menggunakan bahasa indonesia dan bahasa inggris dalam tombol diubah menjadi bahasa Indonesia sehingga penggunaan bahasa menjadi konsisten.

Hasil analisis ujicoba perseorangan, kelompok kecil dan kelompok besar melibatkan mahasiswa semester III Program Studi Manajemen Informatika Politeknik Ganesha Guru. Dalam ujicoba tersebut sebagian besar mahasiswa menyatakan bahwa respon belajarnya meningkat setelah belajar menggunakan multimedia interaktif model games, beberapa saran yang diberikan yaitu menambah model game lain, sehingga multimedia interaktif lebih menarik. Menurut Mulyadi (2010) dalam papernya menjelaskan bahwa Instructional games merupakan perangkat lunak yang di desain untuk meningkatkan respon dan motivasi dengan menambahkan aturan permainan dan atau kompetisi dalam aktivitas pembelajaran. Instructional games menyediakan lingkungan menarik dimana siswa harus mengikuti aturan yang telah dijelaskan sebelumnya dan berusaha untuk mencapai tujuan yang menantang. 


\section{Simpulan dan saran}

Simpulan dari penelitian dapat dijabarkan sebagai berikut: 1) Pengembangan multimedia interaktif model games pada mata kuliah organisasi dan arsitektur komputer dibuat dengan menggunakan aplikasi Adobe Flash Cs 5, dengan mengacu pada desain storyboard yang dibuat, dalam proses pengembangan produk melewati tahap perancangan, pengembangan, finishing hingga ke tahap distribusi dengan mempublish ke dalam bentuk.exe. sehingga menghasilkan produk multimedia interaktif yang layak digunakan. 2) Hasil analisis ujicoba dilaksanakan dengan melibatkan ahli isi, ahli media dan ahli desain pembelajaran, ujicoba tersebut menyatakan bahwa Multimedia interaktif model games pada mata kuliah organisasi dan arsitektur komputer layak digunakan di Politeknik Ganesha Guru, dan 3) Hasil analisis ujicoba perseorangan, kelompok kecil dan kelompok besar melibatkan mahasiswa semester III Program Studi Manajemen Informatika Politeknik Ganesha Guru. Dalam ujicoba tersebut sebagian besar mahasiswa menyatakan bahwa respon belajarnya meningkat setelah belajar menggunakan multimedia interaktif model games

Adapun saran dari penelitian ini adalah, 1. Pengembangan Multimedia Interaktif model games ini dapat dikembangkan menggunakan fitur dan tombol navigasi yang lebih interaktif yang menggunakan konsep games yang lebih menantang,, 2. Pengembangan Multimedia Interaktif model games ini di aplikasikan ke bentuk game lain sehingga mahasiswa tidak cepat bosan, 3. Pengembangan Multimedia Interaktif model games bisa lebih dikembangkan lagi menggunakan aplikasi yang lebih modern dan efektif ke dalam format android sehingga bisa dijalankan menggunakan smartphone.

\section{Daftar Rujukan}

Arikunto, S. 2008. Dasar-dasar evaluasi. Jakarta: Bumi aksara.

Mayer, Richard E. (2014). Incorporating Motivation into Multimedia Learning 29. Learning and Instruction. p. 171-173

Mulyadi, Wisnu (2010), Pengembangan Multimedia Pembelajaran Interaktif CAI Model Instructional Games untuk meningkatkan Motivasi Belajar http://www.google.com/url?sa=t\&rct=j\&q=\&esrc=s\&source=web\&cd=1\&ved=0CCoQFjAA\&url=htt p\%3A\%2F\%2Fcs.upi.edu\%2Fuploads\%2Fpaper_skripsi_dik\%2FPaper_ahmad_wisnu.pdf\&ei=FvXK Uq3IJsOHrQfkyYD4Dw\&usg=AFQjCNHG6lVbmW5hZdln4ji8nvsbfplRKw\&sig2=2 bswRGORHfE_qdX Yk22VA\&bvm=bv.58187178,d.bmk (diakses tanggal 03 September 2013)

Matukhin, Dmitry and Zhitkova, Elena. (2015). Implementing Blended Learning Technology in Higher Professional Education. Procedia-Social and Behaviour Science 206 183-18

Munir, 2010. Prospek Komputer Sebagai Media Pembelajaran Interaktif Dalam Sistem Pendidikan Jarak Jauh di Indonesia [online]. Tersedia: http://file.upi.edu/Direktori/ [29 Juli 2010].

Prismanata, Yoga \& Ismaniati, Christina. (2017). Pengembangan Multimedia Pembelajaran Geografi Berbasis Memory Sport pada Materi Litosfer untuk Peserta Didik SMA. Jurnal Inovasi Teknologi Pendidikan Vol 4 (1). 97-100

Rusman, 2012. Belajar dan Pembelajaran Berbasis Komputer.. Bandung : Alfabeta

Sugiyono. 2012. Statistika Untuk Penelitian. Bandung: ALFABETA 